\title{
The Expanded Public Works Programme: Reflections from South Africa
}

\author{
Oliver Mtapuri \\ University of Limpopo, Turfloop Graduate School of Leadership \\ Edupark, Block B, PO Box 759, Fauna Park 0787, Polokwane, Republic of South Africa \\ Email address: simbaomtapuri@yahoo.com
}

\section{Doi:10.5901/mjss.2014.v5n8p544}

\begin{abstract}
This article reviews public works programmes as a way to alleviate poverty using experiences from around the world in general and South Africa in particular. It interrogates the targeting mechanisms including the question of who benefits, the type of benefit as well as the type of public works. The article argues that the design of public works must take cognizance of whether the initiative is attempting to address chronic and/or transient unemployment as this has a bearing on the thrust of the initiative either to address transient and/or chronic unemployment especially given the multi-dimensional nature of poverty. The article also argues that public works have multiple effects which include distributional effects; real (household) income effects; participation effects; labour market effects; decentralization effects; sustainability effects; investment effects; productivity effects; political economy effects; technical effects; as well as targeting effects. It also argues, using perceptual maps, that when developing public works, it is critical to define the issue which needs to be addressed a priori such as sanitation, HIV/AIDS, food security, unemployment, rural infrastructure development, income, poverty and so forth. The perceptual maps, and the trajectories which they portray, are the major contribution of this article. Public works can span various social and economic sectors such as social services, infrastructure development, early childhood development (ECD) and home- and community-based care (HCBC); community-based waste management, environmental conservation, wildfire management and so forth. The article argues that all interventions should be tested for viability, sustainability and appropriateness within a given context.
\end{abstract}

Keywords: public works, targeting, poverty alleviation, unemployment, benefits

\section{Introduction}

The political economy of apartheid created huge inequalities in terms of wealth distribution; whites had access to economic opportunities while laws, regulations and practices denied black people such opportunities (Venter, 2002:114). This resulted in a duality in which the economy is divided on the basis of race.

South Africa emerged from the pariah apartheid state following the democratic elections of 1994 under the leadership of the now late former President Nelson Mandela. The new dispensation heralded the hope for a new path towards a developmental state. The country boasts a fairly well-developed infrastructure and public and private institutions. Post-1994, the country has recorded decent economic growth rates. However, May (n.d:2, as cited in Maphunye 2011: 616), observes that:

In per capita terms South Africa is an upper-middle-income country, but most South African households experience outright poverty or vulnerability to being poor. In addition, the distribution of income and wealth in South Africa is still the most unequal in the world, and many households still have unsatisfactory access to clean water, energy, health care and education.

Forecasts for South Africa's real GDP growth are 2.5\% in 2012; 3.0\% in 2013; 3.8\% in 2014; and 4.1\% in 2015; while sub-Saharan Africa's economy is expected to grow by $5.7 \%$ and the global economy by $3.6 \%$ (Gordhan, 2012:9). The global economy is experiencing weak growth and high volatility as a result of the financial crisis which began in 2008. The Gini coefficient for South Africa in 2009 was 63.14 (World Bank, 2010). According to Stats SA (2012), the official unemployment rate in the third quarter of 2012 was $25.5 \%$, using the narrow (official) definition.

McCord (2004: 3) contends that there is a link between unemployment and poverty in South Africa because a wage income is a key determinant of poverty. She argues that this problem has been compounded by the existence of a small informal sector and subdued subsistence activity. She further notes that unemployment in South Africa is 'structural, chronic and mass', partly dues to the slump in demand for unskilled labour in the formal sector since the 1970s. This slump in demand relative to supply is the result of 'the decline in the importance of the primary sector, 
technological change, and entry into global economy'. Consequently, the number of new labour market entrants exceeds the new jobs created (McCord, 2004: 3).

Kingdon \& Knight (2005) question why, given such high unemployment rates, the unemployed do not join the informal sector as is the case in other developing countries.

The lack of African self-employment is, to some extent, a legacy of apartheid. Historically the apartheid system repressed the informal activities of black South Africans through such restrictive legislation as the Group Areas Act, harsh licensing, strict zoning regulations, and effective detection and prosecution of offenders. Bouts of slum clearance and other periodic attacks on the illegal spaces within which informal enterprise thrived, served to rid South African cities of black-dominated informal sector niches that were construed as hazardous to public health and stereotyped as unsightly and unsanitary (Rogerson, 1992, cited in Kingdon \& Knight, 2005: 26).

In order to alleviate poverty, the South African government has implemented a social security programme that comprises income support (through grants) and a social wage programme that includes compulsory education for the age cohort seven to 13, free primary health care for all and subsidized housing, water, sanitation, electricity, refuse collection for beneficiaries who qualify (RSA, 2010). The grants provided by the government include old age, disability, child support, the foster care grant and grant in aid. The number of grant beneficiaries increased from 2.6 million in 1997 to 14 million in 2010 (RSA, 2010). Despite these efforts, major challenges remain in the form of persistent high levels of poverty, income and expenditure inequalities and the negative impacts of declining GDP growth especially on the poor.

One of the key programmes initiated by Government to alleviate poverty is the Expanded Public Works Programme (EPWP), 'a broad-based employment-creation and skills development programme' with a focus on public works (RSA, 2010:36). This article focuses on the EPWP, which was initiated in 2004.

\section{Literature Review}

Unemployment among African women and the youth in rural areas and urban slums in South Africa is 'as high as 70-80 percent in some parts of the country' (Antonopoulos, 2009: 5). The private sector has been unable to absorb surplus labour. Meth (2009: 9) argues that 'demand conditions in the labour market matter - if work opportunities do not exist, they have to be created'.

McCutcheon, Padayachee \& Taylor (2011) observe that the EPWP is one of the strategic components of the South African government's strategy to alleviate poverty and generate employment. The EPWP aimed to create at least one million jobs between 2004 and 2009 through generating work opportunities in four sectors of the economy: infrastructure (focusing on roads and civil works), the environment (focusing on coast, alien and fire clearing), social (home and community-based care) and the economic sector (developing small, medium and micro enterprises (SMMEs)). Participation quotas were set as follows: at least $40 \%$ women, $30 \%$ youth and $2 \%$ disabled. McCutcheon et al. (2011: 17) note that the infrastructure budget was R15 billion, while actual expenditure was R42 billion (representing 84\% of the EPWP budget during the first phase). The programmme, which is implemented at national, provincial and local government level, also aspires to enable participants to earn an income after participating in public works through further education and training and establishing SMMEs. von Braun, Teklu, \& Webb (1992) are of the view that labour-intensive programmes suit Africa due to the tradition of community-based labour pooling and sharing arrangements and the limited labour absorptive capacity of the modern sector.

\section{EPWP: Relief or Developmental?}

The EPWP, (2004: 7, cited in McCutcheon et al., 2011) stats that labour intensive methods will used, resulting in the creation of 750000 jobs in infrastructure and 250000 jobs in the environmental, social and economic sectors. In their evaluation of the programme, McCutcheon et al., (2011) note that the costs escalated and that one million jobs were created in the infrastructure sector at a cost of R42 billion against a budget of R15 billion in 2004, demonstrating that the demand for public works was enormous, as well as indicating that the EPWP is more of a relief than a developmental initiative (McCutcheon et al., 2011: 18). Antonopoulos (2009) argues that the budget allocation to the EPWP is small relative to the problem at hand. For example, she notes that for the period 2004-05, the EPWP cost only $0.3 \%$ of GDP and $0.8 \%$ of all government expenditure. McCutcheon et al. (2011) observe that emphasis is placed on the number of jobs, rather than the assets created when reporting results in official government documents. However, they also note that EPWP expenditure reached about R50 billion by 2009 against an initial budget of R21 billion with all funds being generated internally without recourse to donor funding, reflecting 'the scale of internal resources available to South Africa' (McCutcheon et al., 2011: 19). 
McCutcheon et al., (2011: 20) also observe that there was a decline in labour intensity from 26\% at inception to $11.3 \%$ at the end of the first phase in the 2009 financial year due to a recourse to 'business as usual' capital-intensive construction methods as project values rose. Furthermore, Gauteng, a highly urbanized area, and the Eastern Cape provinces accounted for almost half of EPWP expenditure, reflecting a poor uptake in the other provinces with significant rural populations. This raises the question of focused targeting: who is the EPWP targeting, rural or urban populations, or both, as well as the thrust: relief or developmental? Do the decline in intensity and an increase in the EPWP budget reflect a 'business as usual' approach?

\section{Targeting}

Teklu and Asefa's (1999) studies in Kenya and Botswana found that public works have the potential to alter the pattern of demand for labour in rural areas as both the poor and non-poor find additional work opportunities attractive. They also observe that the physically able poor with no assets and little external income tend to dominate public works programmes (PWPs).

Based on experiences in Asia and Latin America, Teklu and Asefa (1999) observe that menial jobs and associated low wages, geographic targeting and the provision of food in lieu of wages are useful for self selection. They also observe that women's participation is higher than men even when the wages are low and where the form of payment is partly or fully food.

\section{Benefits}

Teklu and Asefa (1999) recommend a combination of cash and supplementary food transfers which do not 'crowd out private income transfers' and conclude that the poor will benefit from the asset so created and their participation in the labour market. However, such schemes reduce the intensity of poverty (the poverty gap) rather than lower the incidence of poverty (Teklu and Asefa, 1999: 436).

This view is supported by Antonopoulos (2009), who argues that public works schemes have a profound impact on poverty especially among women who are in the majority in developing countries by transforming their unpaid labour into paid employment as well as enhancing their labour market skills.

As such EPWPs have the potential to create jobs, generate income for beneficiaries, expand tax revenue, promote pro-poor growth and contribute to gender equality (Antonopoulos, 2009). However, Antonopoulos also argues that the impact of the EPWP is diminished by the few job opportunities it creates, as well as their short duration (Antonopoulos, 2009). Mashiri, Chakwizira \& Nhemachena (2009, cited in Chakwizira, 2010:247) found that beneficiaries in the Siyatentela programme in Mpumalanga, South Africa, used the income from the EPWP to purchase food, refrigerators and stoves; start women's savings clubs; and build brick houses, while some invested in poultry and home gardens. Furthermore, McCord (2003: 34) argues that public works have the potential to promote local democracy through community participation.

Soumyendra Kishore Datta \& Krishna Singh (2012: 452) state that women from Birbhum district of India derived the following benefits from participating in public works: an improved standard of living; less borrowing from shops; perceptions of increased food security, the freedom to buy and pay immediately; and the opportunity to mix with others, as well as the possibility of earning the same as men. Turning to South Africa, Antonopoulos (2009) observes the following benefits from participating in public works schemes: a sense of self-esteem and self-worth; the ability to save and dress better; the potential for the emergence of small businesses; enhancement of human capital; post-training certification of participants; a reduction in out-migration; enhanced social inclusion; a reduction in crime and enhanced gender equality. Furthermore, the delivery of home-based care and early childhood development services within the context of the EPWP reduces demands on women's time for unpaid care work (Antonopoulos, 2009). On the one hand, Chakwizira (2010:245) argues that if the objective is poverty reduction, this brings into question the targeting of youth and men and also exposes the tension between the many objectives associated with the South African EPWP. In contrast, Magadlela \& Mdzeke (2004) question the wisdom of giving women preferential treatment, as men also suffer unemployment. Drawing on experiences in India, Krishnaraj et al. (2004, cited in Soumyendra Kishore Datta \& Krishna Singh, 2012) argue that women may be attracted to participate in NREGA jobs because they do not involve specific knowledge and skills.

The benefits derived from the waste management system in Cape Town include the expansion of service delivery to residents in informal settlements; enhanced responsibility and involvement of residents in planning and caring for their environment; greater awareness of the cost of service delivery among residents; cleaner and hygienic neighbourhoods 
and skills upgrading through on-the job-training (Parnell, Douglas \& Boulle, 2005). The programme was financially and political feasible because it was part and parcel of the City's service delivery strategy; and was cost-effective because refuse could be removed from a dwelling at half the normal price (Parnell, Douglas \& Boulle, 2005).

However, Chakwizira (2010:245) observes that, 'The limited scale of employment opportunities and the short-term duration of employment for each worker offered by the EPWP make it unlikely to have a significant impact on unemployment and poverty at household or national level'. Hence, Parnell, Douglas \& Boulle (2005) argue that what is needed is 'wider economic development, redistribution and equitable development, along with targeted programmes [to] provide a sustainable basis for pro-poor city development'. McCord posits that non-income benefits such as adults not skipping meals, improvement in school attendance and more regular observation of social ceremonies by the poor are positive benefits of the EPWP (McCord 2004: 11). She argues that PWPs are applicable where unemployment is transient and not chronic, as is the case in South Africa.

Mashiri \& Mahapa (2002, cited in Chakwizira, 2010:247) observe that the economic benefits, in terms of assets created, under public works are 'extremely limited and anecdotal'. For example, they note that the Tshitwe road upgrading in Limpopo did not increase the circulation of money within the community because the expected increased passenger traffic on the road and access to markets did not materialize. They attribute this to lack of consultation with local communities regarding asset selection and prioritization.

McCord (2004a: 11) argues that income from public works is consumed rather than invested, because of the short duration of employment and the low wages, which militates against the accumulation of funds. Secondary benefits in the form of local development or the growth of micro-enterprises were not realised because of "lack of access to microfinance facilities, and the limited nature of the local market, a situation which was exacerbated by lack of integration with other development initiatives'. McCord (2004b) contends that, based on the experience of KwaZulu-Natal's Zibambele programme, regular, flexible, predictable, long-term employment and acceptance of substitute labour were highly valued by participants in public works. She adds that a 'first-come first-served', or lottery-based approach is inappropriate if social protection is the objective.

\section{Types of Public Works}

While many countries focus on infrastructure projects, Antonopoulos (2009) observes that South Africa is unique in that it has extended public works to social services to include early childhood development (ECD) and home- and communitybased care (HCBC), recognizing that these should also be paid work. HCBC and ECD work entails caring for the sick and terminally ill, child minding and the creation of a clean and nurturing environment necessary for the physical and psychological development of children. This entails engaging child care workers, nutrition workers, school clerical workers, cooks, vegetable gardeners, administrators, community health workers, health officers, and so on (Antonopoulos, 2009). Parnell, Douglas \& Boulle (2005) argue that the community-based waste management system in Cape Town, which undertakes refuse collection and area clearing in informal settlements, is labour-intensive, provides skills development, promotes social cohesion and creates jobs for vulnerable groups.

Magadlela \& Mdzeke (2004) argue that the Working for Water programme, an environmental conservation project which focused on clearing invasive alien plants, had both ecological and social development benefits in that its training component focused on training in work-related activities (such as skills in the use of herbicides and worker safety), in health (HIVIAIDS); contractor development; the re-integration of ex-offenders by giving them work; raising public awareness through an education campaign on invasive aliens; and the setting up of partnerships with nurseries so that they do not sell invasive alien plants.

Parnell, Douglas \& Boulle (2005) observe that the Ukuvuka Campaign, also in Cape Town, was established as an independent agency through a public-private partnership for wildfire management (technical), to clear invasive alien plants (technical) and for poverty relief (developmental), with environmental and social objectives as well as training and empowerment ambitions. The Campaign deliberately discarded cheaper biological and mechanical means to clear invasive alien plants in favour of labour-intensive works. Thus the programme focused on public rather than private land in order to create demand from private landowners for clearing their land.

The project failed because alien plant clearing requires extensive management and administrative support and uses task-based methods; the training provided was haphazard and of insufficient quality to ensure sustainability. Furthermore, the high wages that were negotiated undermined the project's viability (Parnell, Douglas \& Boulle, 2005). As a result, $80 \%$ of the service providers registered with the City, the Public Works Department or the Western Cape Provincial Government collapsed after the Campaign ended (Parnell, Douglas \& Boulle, 2005). This suggests that the conception and thrust of public works must be well thought out. A multiplicity of thrusts may work against the noble ideals 
embedded in their conception, leading to failure.

\section{Possible New Trajectories and Avenues}

It is possible for municipalities to outsource service delivery components to private contractors. Parnell, Douglas \& Boulle (2005) argue that such outsourcing could facilitate the empowerment of community contractors, stimulate local economic development and enhance community ownership of the service. However, in areas where the City of Cape Town had fulltime refuse collection employees, residents demanded a community-based waste management system, while the trade unions were not happy with community-based outsourcing of services (Parnell, Douglas \& Boulle, 2005).

Phillips (2004: 2) maintains that PWPs do not have the capacity to solve South Africa's unemployment problems as they represent 'an array of short to medium-term interventions aimed at alleviating the poverty associated with unemployment, with a particular focus on able-bodied but unskilled adults. PWP's should be viewed as complementary to social grants, and not as an alternative to social grants, because they cannot provide for all of those who are in need' (Phillips, 2004: 2).

Phillips (2004: 4) also argues that it is prudent to focus PWPs in sectors which are growing to avoid displacing the long-term employed, while trying to absorb new labour entrants. She laments the little time devoted to planning and setting up the necessary institutional capacity, the multiplicity of small projects that diminish the impact of economies of scale, the duplication of training costs and the overloading of the programme with many objectives, 'with the result that the programme fails to achieve any of them'.

McCord (2003: 24) avers that there is a need to increase the budget allocated to the programme, as well as to rectify associated institutional constraints such as the dearth of project management skills at both government and community levels. Constraints include 'duplication of effort by different line ministries, lack of efficiencies of scale, lack of social development expertise, limited community participation, and the lack of credible Integrated Development Plans to guide strategic asset selection and promote departmental coordination'. These problems have contributed to the poor selection of projects and the inability to spend the budgets allocated. She further argues that the inclusion of a social development agenda in the construction work plan could act as a disincentive to the private sector for labour intensification (McCord, 2003: 26). McCord (2003: 33) also identifies the need to link public works to access to microcredit facilities in order for the training offered in PWPs to be useful; lack of access to capital is a disincentive to self employment and could also inhibit the use of experience and entrepreneurial skills acquired under public works. The experience of Malawi's Social Action Fund demonstrated that microfinance inputs, savings, credit, enterprise development and group formation were critical in stimulating micro-enterprises, 'which cannot be achieved through PWP wage transfers alone' (DFID, 2003, cited in McCord, 2004b).

Von Braun, Teklu \& Webb (1992) assert that PWPs can be used for rural development through rural infrastructure provisioning; for food security and even sanitation. They suggest that such programmes must take into account the multisectoral nature of macro-economic policy, trade and pricing policies as well as food and agricultural policies (von Braun, Teklu \& Webb, 1992: 30). They add that, in order to be effective, adequate resources must be available for wages and capital investment - whether private or public, labour or institutional capabilities - all valued at 'social opportunity costs'. Murgai and Ravallion (2005, cited in Meth, 2009: 30) contend that the poverty relief objectives of India's job guarantee schemes could possibly be effectively achieved using social grants.

Soumyendra Kishore Datta \& Krishna Singh (2012: 456) suggest that the NREGS in India should also involve educated youth (post-matric) to raise social awareness about literacy, women's rights, sanitation, balanced diets, health, alcohol abuse, family planning and child care, including the prohibition of child labour.

Turning to the question of flexibility, von Braun, Teklu \& Webb (1992: 30) observe that:

Burkina Faso has adopted a flexible approach: if assets are generated on private land, no wage is paid; if work is conducted at the village level (and involves the whole community), then food should be offered but only for communal consumption at the work site; and where assets such as dams are built, using labour from many communities over long periods (up to nine months), then cash wages should be used.

Kingdon \& Knight (2005) argue that if the motive is poverty alleviation or social protection, older women or femaleheaded households in remote areas would be the most appropriate target. McCord (2004b) maintains that if the objective is both protection and employment, it is equally important to link PWP implementation with other programmes such as the Integrated Sustainable Rural Development Strategy (ISRDS) in order to promote partnerships between government departments and civil society. There is a need to link PWPs to other developmental programmes if the objective is developmental. There is also a need 'to interrogate all interventions for feasibility, efficiency, effectiveness, dependencyreduction, appropriateness, sustainability, gender-sensitivity, incorruptibility, provision of exit mechanisms, (when 
interventions are temporary), administrative costs and adequacy of resources (for the scheme to be viable and doable)' (Mtapuri, 2012).

\section{Discussion}

The enormous challenges facing South Africa demand the creation of sustainable jobs. The design of the EPWP must take into account whether it is attempting to address chronic and/or transient unemployment. This will determine the thrust of the initiative. Some components of the programme may address symptoms of transient unemployment, while others might be geared towards addressing chronic unemployment. Linked to this is the question of how to address the multi-dimensional nature of poverty.

The perceptual map below illustrates the type of decisions that have to be made. In that map two variables are examined, namely asset creation versus length of employment - long-term or short-term. Questions will have to be asked whether the focus is on employment or on the assets. If the focus is on the asset, high value asset creation should be the objective as opposed to merely 'digging holes'. For instance, the upper left hand quadrant represents asset creation and the creation of long-term employment. This is ideal when the objective is to address chronic unemployment. The lower left hand quadrant represents a situation in which the macro-economic environment has created conditions for both chronic and transient unemployment. In that case, long-term unemployment and digging of holes' may be condoned such that both those who are in long-term unemployment as well as those in transient unemployment may have to be accommodated using the same interventions. The upper right quadrant opens up possibilities to create high value assets using 'transient labour'. The lower right hand quadrant typifies 'transient labour' which is short term and engaged in 'digging holes' to address the problem of transient unemployment.

Figure 1: Perceptual Map

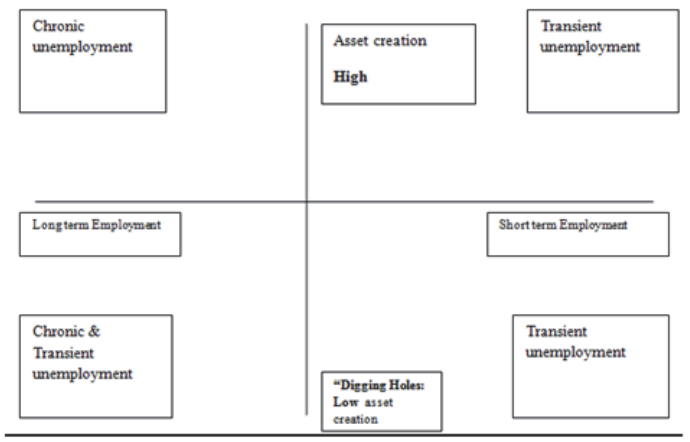

In crafting interventions, it requires interrogating whether grants or public works will have the greatest impact. This is also linked to the amount of resources available to the state. It has been observed that public works do have social and human capital benefits, particularly for women. As such, PWPs have multiple effects. These include distributional effects; real income effects; intra-household income effects; employment effects; labour market effects; decentralization effects; sustainability effects; investment effects; and tax effects. There are also participation effects; productivity effects; political economy effects; technical effects; and targeting effects. Therefore, when crafting public works, it is important to introduce the concept of 'Income plus concept/cash plus concept' meaning that there must be some complementaries in the offering. For example, poverty relief projects could provide beneficiaries with income plus food; income plus training; or income plus something else depending on specific needs. It is also important to consider the post-income phase after the projects have been wound up. Resources as well as institutional arrangements are important to the success of PWPs. Strong institutional arrangements are key to the success of public works.

The perceptual map below (Fig 2) illustrates the nexus between provision of high wages and participation. In the upper left hand quadrant, participation is narrow while the wage is high. This means that rationed participation will have to prevail. It also assumes that resources are available. This may be done to allow people to escape poverty. The lower left hand quadrant reflects a situation in which there are resource constraints such that wages are low and participation is narrow. This results in rationed participation. The upper right quadrant shows a potential non-rationed participation. It is a situation in which high wages would be provided while allowing for wide participation. Such a scenario militates against public works. This may not apply in situations of chronic poverty and severe resource constraints. The lower right hand 
quadrant shows a situation in which there is open participation characterised by low wages and wide participation. This could exemplify areas in which poverty is widespread.

Figure 2: Perceptual Map

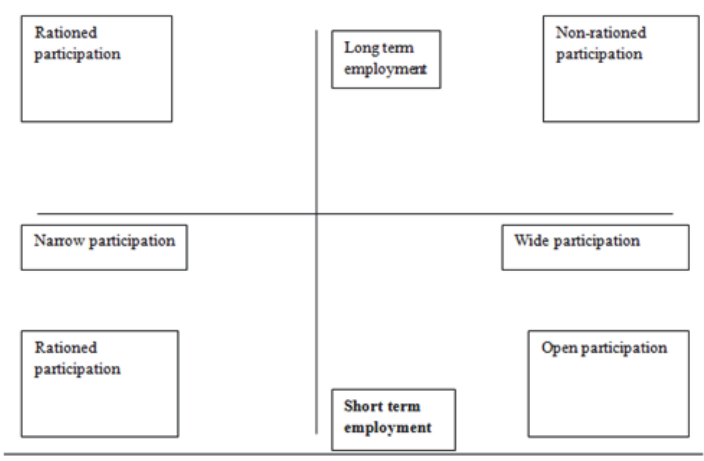

In a nutshell, in developing public works, it is important to define the issue. Is it about sanitation? Is it about HIVIAIDS? Is it about food security? Is it about rural infrastructure development? Is it about income (grants)? Is it about poverty? Is it about (un)employment (chronic or transient)? The answers to these questions will solicit different responses and therefore impact the design of the intervention. It also very important to take the macro-economic and global environments into account.

The perceptual map below (Fig 3) juxtaposes long-term employment versus the payment form - wage/cash or in kind. In the upper left hand quadrant, the provision of long-term employment with wage or cash is suited to address chronic poverty. When the wage/cash is provided on a short-term basis this would be meant to address transient poverty which is exemplified in the lower left hand quadrant. The upper right quadrant shows a situation in which long-term employment is reward with in-kind provisioning. This could be utilised in hyper-inflationary environments to cushion the participants against the adverse impacts of high inflation.

The lower right hand quadrant represents a situation in which short-term employment is provided while payments for participation are made in-kind. This could represent a situation where there is scarcity of cash and abundance of inkind provisions. It is also ideal to address transient poverty where the intervention is targeted. It should be noted that there could be 'in-between cases' at the intersection of the quadrants.

Figure 3: Perceptual Map

\section{Conclusion}

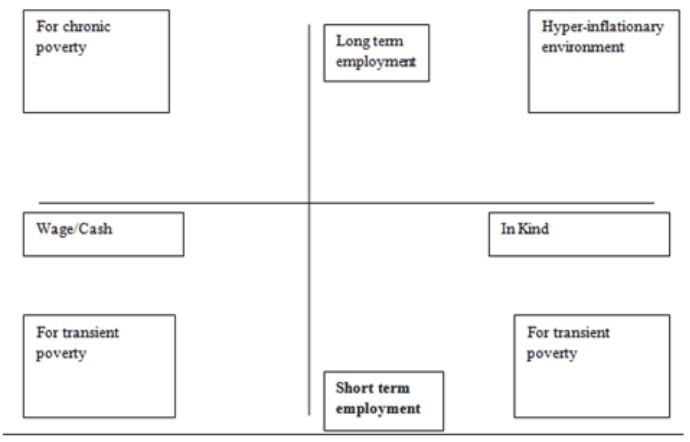

This article looked at unemployment and poverty situation in South Africa. It also examined the current programme initiated by the Government since 2004 to alleviate poverty - the Expanded Public Works Programme (EPWP) which is implemented at national, provincial and local government level. An evaluation of the programme is done using various literature sources. Targeting appears redundant where unemployment and poverty are widespread and rife. The benefits of public works include asset creation, an income, reduction in the intensity of poverty, participation in the labour market, transforming women's unpaid labour into paid employment, community participation, political expediency and so forth. 
The impacts of public works are diminished by the short duration of the interventions and the limited employment opportunities so created. Paucity of micro-finance militated against the formation of small enterprises.

Public works can span various social and economic sectors. In South Africa, public works were extended to include social services such as early childhood development (ECD) and home- and community-based care (HCBC); communitybased waste management, Working for Water programme - which is an environmental conservation project, wildfire management and so forth.

Problems identified in the case of South Africa include the inability to utilize the allocated budgets due to technical constraints, duplication of efforts between ministries and poor selection of projects. As such, rural development through construction of infrastructure and food security opens up new possibilities in the execution of public works. All interventions should be tested for appropriateness, viability and sustainability.

\section{References}

Antonopoulos, R. (2009). Promoting gender equality through stimulus packages and public job creation: Lessons learned from South Africa's Expanded public Works Programme, Public policy brief // Jerome Levy Economics Institute of Bard College, No. 101, http://hdl.handle.net/10419/54243

Chakwizira, J. (2010). Stretching the Concept of the Expanded Pubic Works Programme in South Africa: Tracing the footsteps and gauging the footprints - The unfinished rural development transformation story, Proceedings of the 29th Southern African Transport Conference (SATC 2010) organized by Conference Planners, 16-19 August 2010, Pretoria

Datta, S.K., \& Singh, K. (2012). Women's Job Participation in and Efficiency of NREGA Program-Case Study of a Poor District in India, International Journal of Public Administration, 35:7, 448-457

Gordhan, P. (2012). Republic of South Africa Budget Speech 2012. Government Printers, Pretoria.

Kingdon, G \& Knight, J. (2005). Unemployment in South Africa, 1995-2003: causes, problems and policies. Paper by the Economic and Social Research Council (ESRC) Global Poverty Research Group. \# GPRG-WPS-010. Available at http://www.csae.ox.ac.uk/ accessed: 25 May 2013.

Magadlela, D \& Mdzeke, N., (2004). Social benefits in the Working for Water programme as a public works initiative, South African Journal of Science, Vol. 100, p. $94-96$.

Maphunye, K.J. (2011). 'The Relevance of the Developmental State Model to South Africa's and Botswana's Public Services: A Comparative Perspective', Journal of Public Administration, Vol. 46, No.1.

McCord, A. (2004a). Public works and overcoming under-development in South Africa, Conference on Conference on Overcoming Underdevelopment in South Africa's Second Economy, jointly organized by UNDP, HSRC \& DBSA in 2004.

McCord, A. (2004b). Policy Expectations and Programme Reality: The Poverty Reduction and Labour Market Impact of Two Public Works Programmes in South Africa. Economics and Statistics Analysis Unit Public Works Research Project Working Paper \# 8. Overseas Development Institute: London.

McCord A, (2003). An overview of the performance and potential of public works programmes in South Africa, Centre for Social Science Research, University of Cape Town: Cape Town

McCutcheon, R., Padayachee, M., \& Taylor, P. F. (2011). An in-depth examination of the Expanded Public Works Programme, IMESA: Pretoria.

Meth, C. (2009). 'Active' Labour Market Policies and 'Activation' in South Africa, with passing reference to the Expanded Public Works Programme, and to youth unemployment. Paper was presented at the 'Civil society conference towards a roadmap on social security' in Johannesburg, 19th - 20th March 2009, convened by the Studies in Poverty and Inequality Institute (SPII), Johannesburg

Mtapuri, O. (2012). A review of social protection programmes in Zimbabwe: Lessons Learnt. The Social Work Practitioner-Researcher. Vol 24(3), pp. 365 - 383. (November 2012).

Parnell, S., Douglas, S \& Boulle, J. (2005). Institutionalising pro-poor local economic development through expanded public works in the urban environment of Cape Town, Africa Insight, Vol 35 (4), December 2005.

Phillips, S. (2004). The Expanded Public Works Programme (EPWP): Overcoming underdevelopment in South Africa's second economy, Conference jointly hosted by the UNDP, HSRC and DBSA, 28 \& 29 October 2004.

RSA. (2009). Development Indicators, the Presidency - Republic of South Africa, Government Printers, Pretoria.In http://www.thepresidency.gov.za/learning/me/indicators/2009/indicators.pdf accessed 12 January 2013.

Stats SA. (2012). Key Indicators, Quarterly Labour Force Survey - Quarter 4. In http://www.statssa.gov.za/keyindicators/keyindicators.asp accessed 3 January 2013.

RSA, (2010). Millennium Development Goals Country Report 2010. In http://www.statssa.gov.za/news_archive/Docs/MDGR_2010.pdf accessed 18 September 2012.

Teklu, T., \& Asefa, S., (1999). Who Participates in Labor-Intensive Public Works in Sub-Saharan Africa? Evidence from Rural Botswana and Kenya, World Development, Vol. 27, No. 2, pp. 431-38.

Venter, A. (2002). 'The politics of social protection in South Africa: Reflections on establishing a welfare state', Acta Academica, Vol. 34, №. 2.

von Braun J., Teklu, T., \& Webb, P. (1992). Labour-intensive public works for food security in Africa: past experience and future potential. International Labour Review, Vol 31(1): 19-33.

World Bank. (2010) Gini Index In http://data.worldbank.org/indicator/SI.POV.GINI accessed 12 January 2013 